\title{
The Behaviors of Wine Grape Varieties with Biological Resistant, in Blaj Vineyard Conditions
}

\author{
Claudiu-Ioan BUNEA ${ }^{1)}$, Nastasia POP ${ }^{1)}$, Florin BORA ${ }^{1)}$, Daniela POPESCU ${ }^{2 *}$, Andrea BUNEA ${ }^{1)}$ \\ ${ }^{1)}$ University of Agricultural Sciences and Veterinary Medicine, 3-5 Manastur St., Cluj-Napoca, Romania. \\ 2) Research-Development Station for Viticulture and Enology, 2 Gh. Baritiu St., Blaj, Romania. \\ ${ }^{*}$ Corresponding author, e-mail: hodordaniela@yahoo.com
}

Bulletin UASVM Horticulture 71(2) / 2014

Print ISSN 1843-5254, Electronic ISSN 1843-5394

Doi:10.15835/buasvmcn-hort:10451

\begin{abstract}
The creation of varieties with high biological resistant to specific diseases of the vine but also to the extreme weather conditions (frost) represents a great advantage by being able to avoid phytosanitary products. But besides these goals, the breeder must have into account the productivity and quality, these characters being of major importance for the farmer. In the natural conditions of Blaj vineyard, in 2013, the registries results show that 'Brumăriu' obtained the biggest values for: sugar level (195.7 g/l), absolute fertility coefficient (1.7), relative fertility coefficient (1.6) and relative productivity index (239.5 g). The most early variety was 'Rubin', witch maturated at $20^{\text {th }}$ of september. 'Radames' offers high productivity (over $25 \mathrm{t} / \mathrm{ha}$ ) but the destination is for getting current consumption wines.
\end{abstract}

Keywords: maturity evolution, productivity, quality, wine grapes, yield

Introduction. In the context of climate change (Tudorache et al., 2013) and consumer preferences (Namolosan and Antoce, 2000) is necessary to know the evolution of biological and agricultural technique and the adaptability of new varieties created and homologated (Sestras, 2004). Obtaining through genetic restructuring of resistant varieties or at least tolerant at main specific diseases, was imposed as the most convenient alternative to increase productivity and efficiency of vine culture by untreated or reducing the number of treatments and of course reducing the energy consumption (Moldovan et al., 2001). According to Grecu (2011), currently in Romania, from category resistant varieties are admitted to propagation 12 species: 3 varieties for table grapes ('Valeria', 'Argenssis', 'Moldova-sel.'), 8 varieties for white wines ('Mt. de Pölös', 'Brumariu', 'Radames', 'Rubin', 'Valérien-sel. ', 'Rosina' and 'Seyval-sel.') and one variety for red wine ('Purpuriu'), these being grown mainly in people's yards and garden.

Aims and objectives. The goal of this study is to analyze the productivity, quality, maturity evolution and yield of three varieties with high biological resistant cultivated in Blaj, Târnave vineyard.
Materials and methods. This paper presents the behaviors of 3 grapes varieties: 'Radames', 'Rubin' and 'Brumăriu' that were obtained by breeding at R.D.S.V.E. Blaj. All the studies were made in 2013, in the experimental field at R.D.S.V.E. Blaj, and focused on quality and productivity items such as: titrabile acidity $\left(\mathrm{g} / \mathrm{I}_{2} \mathrm{SO}_{4}\right)$, sugar content $(\mathrm{g} / \mathrm{l}), \mathrm{pH}$ level, medium weight of grapes bunches, weight of 100 grapes, absolute productivity index, relative productivity index, absolute and relative fertility coefficients, and yield ( $\mathrm{t} / \mathrm{ha}$ )..

Results and Discussion. In the climatic conditions of the year 2013, the bud breaking was made in third decade of April, for all three varieties studied. Because the first frost was recorded in October 4, length of vegetation period amounted to a total of about 175 days and useful thermal balance value of $1521.6^{\circ} \mathrm{C}$ (Tab. 1 ), specific to this culture area (Antoce et al., 2013). Al though in terms of vegetation growth the all three varieties ('Radames' and 'Brumariu' - high growth and 'Rubin' - medium growth), showed a higher fertility (Tab. 2). The registries results show that 'Brumăriu' obtained the biggest values for: sugar content $(195.7 \mathrm{~g} / \mathrm{l})$, absolute fertility coefficient (1.7), relative fertility coefficient (1.6) and relative 
Tab. 1 Development of main phenophases and the useful thermal balance $\left({ }^{\circ} \mathrm{C}\right)$ recorded per vegetation stage, in 2013, in Blaj Vineyard

\begin{tabular}{|c|c|c|c|c|c|c|c|c|c|c|c|c|}
\hline \multirow{2}{*}{ Varieties } & \multicolumn{2}{|c|}{ Bud breaking } & \multicolumn{2}{|c|}{ Flowering } & \multicolumn{2}{|c|}{ Veraison } & \multicolumn{2}{|c|}{ Full maturation } & \multicolumn{2}{|c|}{ Leaves fall } & \multirow{2}{*}{$\sum \mathrm{tu}^{*}$} & \multirow{2}{*}{$\begin{array}{c}\text { Vegetation } \\
\text { period } \\
\text { (days) }\end{array}$} \\
\hline & Data & $\sum \mathrm{tu}^{* *}$ & Period & $\sum \mathrm{tu}$ & Data & $\sum \mathrm{tu}$ & Data & $\sum \mathrm{tu}$ & Data & $\sum$ tu & & \\
\hline 'Radames' & 22.04 & 19.6 & $30.05-12.06$ & 303.1 & 20.08 & 948.4 & 20.09 & 224.1 & 04.10 . & 26.4 & 1521.6 & 175 \\
\hline 'Rubin' & 21.04 & 15.3 & $30.05-10.06$ & 307.4 & 21.08 & 961.9 & 25.09 & 231.2 & 04.10 . & 5.8 & 1521.6 & 176 \\
\hline 'Brumariu' & 23.04 & 23.6 & 04.06-12.06 & 323.1 & 20.08 & 924.4 & 25.09 & 244.7 & 04.10 . & 5.8 & 1521.6 & 174 \\
\hline
\end{tabular}

${ }^{*} \sum \mathrm{tu}=$ Useful thermal balance - summarizes the differences of temperatures exceeding $10^{\circ} \mathrm{C}$ biological threshold

**The value of $\sum$ tu calculated from weeping ("biological zero") up to bud breaking

Tab. 2 The fertility and productivity of grape varieties, in 2013, in Blaj Vineyard

\begin{tabular}{|c|c|c|c|c|c|c|c|c|c|c|}
\hline \multirow[t]{2}{*}{$\mathrm{Nr}$. } & \multirow[t]{2}{*}{ Variety } & \multicolumn{2}{|c|}{$\begin{array}{c}\text { The percentage } \\
\text { of fertile } \\
\text { shoots }(\%)\end{array}$} & \multicolumn{2}{|c|}{ Fertility coefficient } & \multirow{2}{*}{$\begin{array}{l}\text { Weight of } \\
100 \text { grape } \\
\text { grains }(\mathrm{g})\end{array}$} & \multirow{2}{*}{$\begin{array}{l}\text { Average } \\
\text { weight of } \\
\text { a grape } \\
\text { bunch (g) }\end{array}$} & \multicolumn{2}{|c|}{ Productivity index } & \multirow[t]{2}{*}{$\begin{array}{l}\text { Production } \\
\text { (t/ha) }\end{array}$} \\
\hline & & Mean & Signif. & Relative & Absolute & & & Relative & Absolute & \\
\hline 1. & 'Radames' & 71.0 & ooo & 1.2 & 1.6 & 170.1 & 198.5 & 228.2 & 323.5 & 25.0 \\
\hline 2. & 'Rubin' & 83.0 & - & 1.4 & 1.7 & 137.8 & 111.0 & 155.5 & 188.8 & 21.1 \\
\hline 3. & 'Brumariu' & 93.0 & $* * *$ & 1.6 & 1.7 & 164.5 & 152.6 & 239.5 & 256.3 & 23.3 \\
\hline \multicolumn{2}{|c|}{ Mean of experiment } & 82.3 & - & 1.4 & 1.7 & 157.5 & 154.0 & 207.8 & 256.2 & 23.1 \\
\hline
\end{tabular}

$*, * *, * * * /{ }^{0,00,000}$ Significant at $\mathrm{P}<0.05 ; 0.01$ and $0.001\left(*,, *, * * *\right.$ positive, ${ }^{0,00,000}$ negative)

Tab. 3 The quality of production obtained in 2013, in Blaj Vineyard

\begin{tabular}{|c|c|c|c|c|c|c|}
\hline \multirow[t]{2}{*}{ Nr. } & \multirow[t]{2}{*}{ Variety } & \multicolumn{2}{|c|}{ Sugar content of must $(\mathrm{g} / \mathrm{l})$} & \multicolumn{2}{|c|}{$\begin{array}{l}\text { Total acidity } \\
\left(\mathrm{g} / \mathrm{l} \mathrm{H}_{2} \mathrm{SO}_{4}\right)\end{array}$} & \multirow{2}{*}{$\begin{array}{l}\text { pH-ul } \\
\text { of must }\end{array}$} \\
\hline & & Mean & Signif. & Mean & Signif. & \\
\hline 1. & 'Radames' & 178.6 & 000 & 5.2 & 0 & 3.31 \\
\hline 2. & 'Rubin' & 192.3 & $* * *$ & 6.5 & $*$ & 3.31 \\
\hline 3. & 'Brumariu' & 195.7 & $* * *$ & 5.7 & - & 3.26 \\
\hline \multicolumn{2}{|c|}{ Mean of experiment } & 188.9 & - & 5.8 & - & 3.29 \\
\hline
\end{tabular}

$*, * *, * * * / 0,00,000$ Significant at $\mathrm{P}<0.05 ; 0.01$ and $0.001\left({ }^{* * *}, * * *\right.$ positive, ${ }^{0,00,000}$ negative)

productivity index (239.5 g), these values being higher than those obtained by Moldovan et al. (2001).'Rubin' had the biggest value for acidity $\left(6.5 \mathrm{~g} / \mathrm{l} \mathrm{H}_{2} \mathrm{SO}_{4}\right)$. 'Radames' had the greatest medium weight of grapes bunches (198.5 g), and the biggest yield ( $25 \mathrm{t} / \mathrm{ha}$ ) (Tab.3).

Conclusion. According to the results obtained 'Brumăriu' seems to be the most valuable variety, followed by 'Radames' and 'Rubin', in eco-climatic conditions of 2013, Blaj.

The wines that can be obtained from the three varieties studied are dry wines for current consumption, but they can be used to obtain distillates. These varieties can successfully replace direct producer hybrids (DPH).

\section{REFERENCES}

1. Arina OA, Nămoloșanu I, Dușa D, Mereanu D, Rebigan C, Nicolau V, Călugăru L, 2013. Some Considerations Regarding the Grapevine Variety Assortment and Wine Categories in Romania in Recent Years. Bulletin de l'OIV, Vol. 86 - $\mathrm{N}^{\circ} 983-$ 984-985, pg: 27-44.

2. Grecu V (2011). Resistant grapes varieties and their culture particularities. pg: 54-55. Ed. M.A.S.T. Bucharest.

3. Moldovan SD, Iliescu M, Bernaz G (2001). 55 years of scientific research to viticulture and vinification in Transylvania. pg. 127-133. Ed. Poliam.

4. Namolosan I, Antoce OA (2000). Romanian viticulture on the verge of the third millennium. Die Wein Wissenschaft, Vitic. Enol. Sci., 55(2): 67-72.

5. Tudorache A, Pircalabu L, Porumb R, Tomoiaga L, Iliescu M, Enache V, Simion C, Damian D, Anamaria P, Ghica M (2013). Description des Climats dans les Centres Viticoles Principaux de Roumanie. Bulletin de l’O.I.V. Vol. 86, № 983-984-985: 4558.

6. Sestras R (2004). Breeding of horticultural species. pg: 27-48. Ed. AcademicPres. 